\title{
Do Work Life Balance, Organizational Pride and Job Satisfaction Affect the Intention to Leave?
}

\author{
Nilawati Fiernaningsih, Umar Nimran, Kusdi Rahardjo, and Zainul Arifin
}

\begin{abstract}
This research intends to investigate the effect of work life balance to the organizational pride, job satisfaction, and to the intention to leave; and the effect of organizational pride and job satisfaction to the intention to leave. The data is collected by using questionnaires from 209 employees of four and five stars hotels in the Malang city-East java Province-Indonesia and then the data is analyzed by using GeSCA. Results show that the work life balance significantly affects the organizational pride and job satisfaction, however, the work life balance does not significantly affect the intention to leave. In addition, the organizational pride significantly effects the job satisfaction and the intention to leave; and the job satisfaction significantly affects the intention to leave. The originality value: this research investigates the direct as well as indirect effect of work life balance to the intention to leave through the organizational pride and job satisfaction, so it can show the important role of work life balance, organizational pride, and job satisfaction to the intention to leave.
\end{abstract}

Keywords: work life balance, organizational pride, job satisfaction, intention to leave, industrial hotel, Indonesia.

\section{INTRODUCTION}

The phenomenon of the increasing number of hotels gives the wider opportunities for the employees to turnover to the other hotel. In addition, for the hotel, the high employees turn-over can disturb the hotel operation.

However, employees are as the pride asset of a company, so the company has to hold the employees by decreasing the intention to leave. The high employees' turnover has the big implication for the company, moreover if the employees have the important and potential role. The impact that is felt by the company like the work atmosphere change due to the entering of new employees, the cost that is spent for training the new employees, the decreasing of service temporary, even until the disturbance of the service process.

The competition between hotels sue the employees to work hard and always giving the best service, so it is decreasing the employees chance to carry out their personal life. Meanwhile, the employees have the personal life that has to be fulfilled. Therefore, the high demand can disturb the personal life, The balance between work and personal life can give the impact on the employees convenience.

Revised Manuscript Received on September 23, 2019

Nilawati Fiernaningsih*, ${ }^{1}$ Doctoral Student, Department of Business Administration, Faculty of Administration, University of Brawijaya, Malang, Indonesia

Umar Nimran, Department of Business Administration, Faculty of Administration, University of Brawijaya, Malang, Indonesia..

Kusdi Rahardjo, Department of Business Administration, Faculty of Administration, University of Brawijaya, Malang, Indonesia.

Zainul Arifin, Department of Business Administration, Faculty of Administration, University of Brawijaya, Malang, Indonesia
Of course he employees evaluates that their work disturb their personal life or not which by the end it will give the impact on the employees willingness to find the new work place.

Work Life Balance (WLB) has been highlighted by the researchers and practitioners of human resources [1]. WLB is as an individual ability to meet the work and commitment in their family life, and the other non-work responsibility [2]. WLB is as a situation that is win-win solution between the employees and the company where the employees have the ability to balance between their work and family life [3]. WLB is proven to have some profits for company like the return on profit [4], the productivity, the work behavior, and the lower turnover intention (Suifan et.al., 2016), and to decrease the work life conflict [5]. Although the WLB has obtained the much attention from the researchers, however, there is the different effect on the different industry [6]. Researches in the developed countries that have the different characteristic of culture with the western counties are important to be carried out. It is due to the practice challenges of the different WLB too. This research is conducted in Indonesia that has collectivist culture characteristic where the employees have the more intends social life than the individual one. So the employees have more difficult in balancing their life.

This research discuss about the effect of work life balance, organizational pride, and job satisfaction to the intention to leave in the hospitality industry. The study about the effect of work life balance and organizational pride to the intention to leave is still limited on the hospitality industry, so it still needed. Hotel is a company that depends on the service quality, so the employee's role in fulfilling the demand and willingness of the hotel customers is very important. The demands on the hotel to be always appear excellent can drain the employee's energy, so their time to undergo their personal life become limited. Therefore, the balance between the personal life and the work life is disturbed. This situation can make the bad imply for the employees because the employees will feel aggrieved and will assess the company has the bad reputation for the employees. It can be implied on the employee satisfaction and by the end it can increase the intention to leave.

This research contributes in giving the empirical proof about the role of WLB, organizational pride, and job satisfaction in decreasing the intention to leave, especially on the hospitality industry in Indonesia which has the trend to have the collectivist culture. Specifically, this research intends: 1) to investigate the effect of WLB to the organizational pride, job satisfaction, and the intention to leave; 2 ) to investigate the effect of organizational pride to the job satisfaction and the intention to leave; 3) to investigate the effect of job satisfaction to the

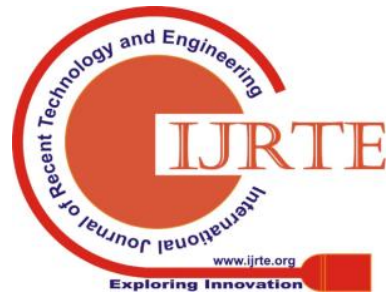


intention to leave. The practical implication is this founding gives insight to the manager that the balance of employees life in the environment is important for muffling the employee willingness to move on work, however, the manager develops the programs that intend to increase the balance between the individual interest of employees and their work so the employees become proud of the company, satisfied to the work, and by the end to have the high loyalty to the company.

\section{MATERIALS AND METHODS}

\section{A. Theoretical Framework}

The social exchange theory can underlie the relation among the related sides in the company. The principal of this theory is if one of the sides gets the benefit from the other side so it has to pay by giving the benefit to the other side (Blan, 1964)/ Employees obtain the benefit from the company in the financial as well as non-financial form. The balance between the work and personal demand are as the important aspect that is considered by the employee. The employee is comfortable when the company facilitates and opens the chance for the employees to undergo their duty of work without ignoring their personal life like their household life, hobby, and the other personal activities.

The benefit that is felt by the employees like the WLB is perceptron as a goodness or award that is accepted from the company, so the employees give the feedback of benefit to the company that is the loyalism of employee to the company. The loyalism of employee is shown by the low willingness of employee to move on the other company as a dedication to the company. The employees are aware that their existences on the company are indispensable and if the employees are moving on so the company will be disadvantages. The previous researches have studied about the relation between company and employee through the social exchange theory [7]. The lower intention to leave is as a employees reward to the company that has given the benefit to themselves so they are able to undergo the personal life well, to be proud of the company and they are satisfied.

\section{B. Literature Review}

\section{B.1. Work Life Balance}

Kalliath and Brough [8] presented that employees had the double role related with their work and household. Not every employee has the chance to balance between work and personal life, although it is important. However, company has the role in helping the employees to balance the two interests. Work-life balance is an individual ability for fulfilling the work and commitment in their family life, and the responsibility in the other non-work [2]. Frame and Hartog (2003) has an opinion that the work-life balance mean that the employees can use their work time freely and flexibly for balancing their work and duty with the other commitment like family, hobby, art, study, and they do not only focused on their work. Clark [9] emphasized that work-life balance is a good satisfied activity at home and work place with the minimum conflict level.

The benefit of WLB for company is presented by Lewison [10] as the decreasing of absence and turnover, the increasing of productivity; the over-work cost is decreasing and the client retention. When the service demand to the customer is high, the employees will be drained of energy to finish their work. The regulation of work time is difficult to be carried out with less flexible and decreasing the employees chance to undergo their personal life. The challenge for company is how the effort to increase the company performance as well as to create the employees welfare, to increase the work satisfaction, to fulfill the family hope and demand, and to fulfill the employees hope as the better life, the more meaningful work life and to be helpful for the employees. Robbins and Coulter [11] offered some programs to create the WLB such as old people care help, education for children, health care, employees welfare, etc.

\section{B.2. Organizational Pride}

Organizational pride is a positive role of individual to their group that is sourced on the other person assessment to the group status [12]. Gouther and Rhein [13] said that the organizational pride consisted of two types such as emotional and attitudinal. The pride that is felt by the individual due to the success of an activity that is related with the organization is as an organizational pride like emotional. Meanwhile the attitudinal pride points to the pride that is felt by individual in the organization which is sourced from the general perception to the organization.

Organizational pride is very valuable for company because it is as the intrinsic motivator for the employees that influences the characteristic and behavior of employees. However, it is consistent with the opinion of Tracy and Robins [14] that pride is traditionally related with the meaningful happy feeling, it means that pride has the consequence to the individual behavior. Appleberg [15] expressed that the organizational pride was positively increasing the employees commitment on the organization so it would imply on the employees decision to keep working on the company. The organizational pride is also increasing the stress endurance of employees. However, it is negatively influencing the employees' willingness to move [16].

\section{B.3. Job Satisfaction}

Locke (1976) defined that the employees work satisfaction was as a fun emotional condition that was produced from the work assessment. Meanwhile Grieshaber et.al [17] defined that work satisfaction was as an aspect that was profitable or non-profitable which the employees saw their work. Work satisfaction is also defined as a level that the employees like their work [18]. Work satisfaction is defined as the emotional feeling and behavior expression for a work. However, feeling is affected by some factors that is related with the work like salary, many types of benefit, recognition, work condition, the relation with co-workers and supervisor, and the others [19]-[20]. According to Herzberd and Mausuer [21], motivation based work satisfaction is divided into two categories that are the internal and external satisfaction. The external satisfaction is related with the factors like payment, promotion, admiration, and the interaction with co-workers while the internal satisfaction is related with the values, social status, position, and the professional responsibility. The individual assessment of work and satisfaction expression or their non-satisfaction can be assumed as the general result and their work constituent. 


\section{B.4. Intention to Leave}

The intention to leave is identic with the turnover intention as to be presented by Miller [22] that intention to leave on the some literatures is also mentioned as turnover intention, anticipated turnover, and intention to quit. According to Kuvaas [23], turnover intention refers to the employees possibility to leave their work and organization by own will. Individual that has high intention to leave is realized with the behavior to resign from work. Intention to leave is the strongest predictor to turnover [24]-[25]. Chen et.al [26] and Fiernaningsih [27] illustrated that the indicator of intention to leave consists of: 1) intention to resign; 2) looking for alternative job; 3) planning to resign; and 4) applying for another job. The high intention to leave will give the negative impact to the stability of company because there is the vacancy that has immediately to be filled. Turnover is also to be able to have impact that is less fun for the employees who still keep working. Mubarok et.al [28] has summarized three categories that are as the causal factor to the turnover intention that are personal and work-related, profession perception, and organizational condition.

\section{Framework of the study and hypotheses} C.1. Relationship Work Life Balance and Organizational Pride

Work life balance is as a situation when the employees are able to play a role well at the work place as well as at home with the minimum conflict [9]. The company contribution in creating the work condition that gives the chance to the employees to be able to divide between the personal role and the role in working has the positive effect for the employees that are the happiness and pride on the company. Machica et.al [29] found that the employee work life balance has the positive relation with the organizational pride. Therefore, the first hypothesis is work life balance has the significant effect to the organizational pride (H1).

\section{C.2. Relationship Work Life Balance and Job Satisfaction}

Employees with the work life balance experience may be more satisfy with their work and life because there is the increasing on the high involvement of employee in the work as well as family life. However, the Work Life Balance (WLB) can affect the employee work satisfaction. The empirical proof was shown by Haar et.al [30]. He found that the WLB had the positive relation with the work satisfaction. Ronda et.al., (2016) found that the relation between the harmonious family and the high employee work result can increase the work-family balance. The positive relation is mediated by work satisfaction and working hours. However, the second hypothesis is the work life balance has the significant effect to the job satisfaction $(\mathrm{H} 2)$.

\section{C.3. Relationship Work Life Balance and Intention to Leave}

Based on the social exchange theory [31], the policy or benefit that has been accepted by the employee from the company cause the interest to repay by maintaining the loyalty to the company. The practice of WLB is as part of the company policy that gives the significant effect to the turnover intention [32]. Noor [33] and Suifan et.al [5] gave the empirical proof that the WLB gives the significant and important negative impact to the turnover intentions. Based on the argumentation above, it can be formulated the hypothesis as follow: H3: Work Life Balance (WLB) has the significant effect to the intention to leave.

\section{C.4. Relationship Organizational Pride and Job Satisfaction}

Proud can stimulate someone to do something better so the work satisfaction will be implemented. Macguca et.al [34] has tested and analyzed the relation between organizational pride and job satisfaction. The result shows that the employees who feel proud with their job of company will also feel the job satisfaction. The result shows that the employees are proud of their job of the company and will feel the job satisfaction. Based on the argumentation, it can be formulated the fourth hypothesis as follow: H4: the organizational pride has the significant effect to the job satisfaction.

\section{C.5. Relationship Organizational Pride and Intention to Leave}

The employees pride to their company stimulate the employees will be more active in working and hang in there to become as the organizational member. According to Gouthier and Rhein [13], organizational pride is as a personal stimulation of the employees. Appleberg [15] presented that the organizational pride has the positive impact to the employees' decision to keep working on their company. Yang and Wittenberg [35] has found that the organizational pride is as one of the factors which gave the big effect to the turnover intention. Kraemer and Gouthier and Rhein [13] will also be found that the organizational pride has a very important role to the turnover intention. Therefore, the fifth hypothesis is as follow: H5: organizational pride has the significant effect to the intention to leave.

\section{C.6. Relationship Job Satisfaction and Intention to Leave}

According to Robbins and Judge [36], one of the impacts of the employees that are not satisfied to their working place is the outgoing response due to the behavior of leaving the organization included to find the new position and to resign. It is as presented by Foreman [37] who said that the work satisfaction was able to decrease the employees' willingness to turnover from company. Raddaha et.al [38] found that the level of work satisfaction of nurse very decisive the intention to leave their work-place. Masum et.al. [39] also found that there was a negative relation between the job satisfaction and the intention to quit. However, the sixth hypothesis is as follow: H6: the job satisfaction is significant influencing to the intention to leave.

\section{Methodology}

\section{D.1. Survey of instrument}

The closed questionnaires are used as the research instrument. The measurement of work-life balance is based on the Mc. Donald and Bradley [40] and Clark [9]. The indicator of work-life balance adapted to Clark (2000) and the indicator of organizational pride referred to Gouthier and Rhein [13] and Machuca et.al [29]. The indicator of job satisfaction referred to Handoko [41], however the indicator of intention to leave adapted to Chen et.al. [26] and Fiernaningsih [27]. All of the variables in this research are measured by using the Likert scale that are gradated between the score of 1 until 5 (strongly disagree until strongly agree). The instrument trial is carried out on the 30 
respondents and the result indicates that the whole items have the correlation coefficient (validation) more than 0.3 and the cronbach's alpha (reliability) is more than 0.6. Therefore, the questionnaires can be used for the further data collecting.

\section{D.2. Data collection}

The analysis unit of this research is the permanent employee on the five stars hotel. The data are collected from 2 five stars hotel and 7 four stars hotel in the Malang City-East java Province during June -July 2018. The populations of this research are 439 employees and the sample size is 209 based on the Slovin formula. The respondents are selected based on the proportional stratified random sampling and the questionnaires are given to the selected respondents.

\section{D.3. Validity and reliability}

The cross-check of validity and reliability uses the convergent and discriminant validity. Table- I presents the analysis result of measurement model on the $2^{\text {nd }}$ order and all of the dimension produce the loading factor that is more than 0.6 and the AVE square roof on each dimension is more than the correlation coefficient among dimension. Therefore, the convergent and discriminant validity of the whole indicator is expressed to be fulfilled.

Table- I. Test result of validity and reliability

\begin{tabular}{|c|c|c|c|c|c|}
\hline Variable and indicators & Loading & SE & $\mathrm{CR}$ & AVE & $\begin{array}{l}\text { Cronbach's } \\
\text { alpha }\end{array}$ \\
\hline \multicolumn{6}{|l|}{ Work Life Balance ${ }^{l}$} \\
\hline Border & 0.868 & 0.023 & $38.17^{*}$ & 0.879 & 0.861 \\
\hline Permeability & 0.858 & 0.023 & $36.89^{*}$ & 0.888 & 0.873 \\
\hline Flexibility & 0.912 & 0.013 & $69.68^{*}$ & 0.863 & 0.841 \\
\hline Blending & 0.915 & 0.014 & $63.6^{*}$ & 0.844 & 0.813 \\
\hline \multicolumn{6}{|l|}{ Organizational Pride $^{l}$} \\
\hline Emotional & 0.957 & 0.008 & $115.41^{*}$ & 0.836 & 0.934 \\
\hline Attitudinal & 0.964 & 0.007 & $136.54^{*}$ & 0.855 & 0.914 \\
\hline \multicolumn{6}{|l|}{ Job Satisfaction $^{\text {I }}$} \\
\hline Co-workers & 0.620 & 0.011 & $58.07^{*}$ & 0.905 & 0.893 \\
\hline Work condition & 0.626 & 0.011 & $58.58^{*}$ & 0.872 & 0.853 \\
\hline Team work & 0.314 & 0.007 & $44.13^{*}$ & 0.895 & 0.883 \\
\hline Work atmosphere & 0.321 & 0.009 & $36.02^{*}$ & 0.843 & 0.81 \\
\hline Protection & 0.313 & 0.007 & $43.99^{*}$ & 0.882 & 0.866 \\
\hline \multicolumn{6}{|l|}{ Intention to Leave ${ }^{2}$} \\
\hline Intention to resign & 0.870 & 0.024 & $35.85^{*}$ & \multirow{4}{*}{0.762} & \multirow{4}{*}{0.895} \\
\hline Looking for alternative job & 0.865 & 0.021 & $41.27^{*}$ & & \\
\hline Planning to resign & 0.885 & 0.02 & $44.77^{*}$ & & \\
\hline Applying for another job & 0.872 & 0.018 & $47.36^{*}$ & & \\
\hline
\end{tabular}

$*$ pvalue $<0.05 ;{ }^{1}=2^{\text {nd }}$ order ${ }^{2}=1^{\text {st }}$ order

\section{RESULTS AND DISCUSSION}

\section{A. Finding}

The respondents of this research are classified based on the gender that consists of male $(64.6 \%)$ and female $(35.4 \%)$; age: $\leq 25$ years $(15.8 \%), 26-35$ years $(47.4 \%), 36-45$ years $(23.9 \%)$, and $\geq 46$ years $(12.9 \%)$; length of work: $\leq 10$ years $(80.9 \%), 11-20$ years $(18.2 \%), 21-30$ years $(0.5 \%)$, and $\geq 30$ years $(0.5 \%)$; marital status: married $(76.6 \%)$ and unmarried $(23.4 \%)$.
However, the analysis tool uses the GeSCA (Goodness of Fit Model) that is used for testing the reliability of model that is formed. The test index that is used in the GSCA analysis is FIT. The result shows that the value of FIT is 0.702 , it indicates that the variance of intention to leave is able to be explained by the whole model in amount of $70.2 \%$, however, the rest in amount of $29.8 \%$ is as the other variable contribution that is not discussed in this research. Fig. 1 presents the final structural model.

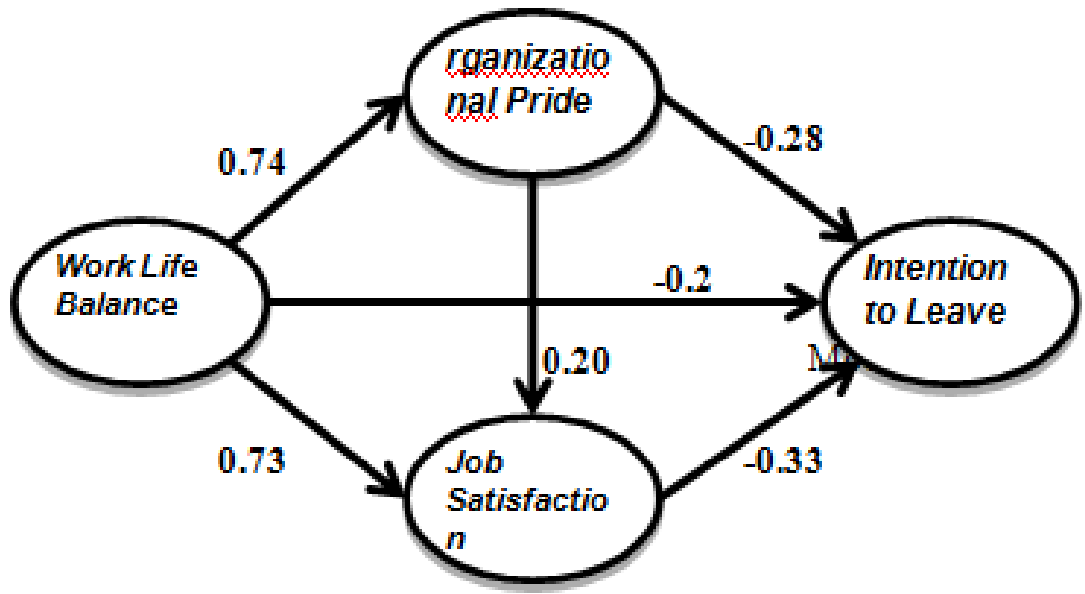

Fig. 1. Final Structural 
The hypothesis test is carried out by comparing the critical ratio (CR) with the t-table (2.00). The hypothesis is accepted if the $\mathrm{CR}$ is more than the t-table. The hypothesis test on the effect of work life balance to the organizational pride produces the $\mathrm{CR}$ in amount of 18.76. It indicates that the value of CR > t-table. Therefore, it can be meant that there is the significant effect of work life balance to the organizational pride. The effect coefficient of work life balance to the organizational citizenship pride is in amount of 0.747 . It expresses that the work life balance has the positive effect to the organizational pride. It means that the better work life balance tends to be able to increase the organizational pride. However, the first hypothesis is accepted.

The hypothesis test of the work life balance effect to the job satisfaction produces the $\mathrm{CR}$ in amount of 9.80. It indicates that the value of $\mathrm{CR}>\mathrm{t}$-table. Therefore, it can be meant that there is the significant effect of work life balance to the job satisfaction. The effect coefficient of work life balance to the job satisfaction is in amount of 0.734 . It indicates that work life balance has the positive effect to the job satisfaction. It means that the better work life balance tends to be able to increase the job satisfaction. However, the second hypothesis is accepted.

The hypothesis test of the work life balance effect to the intention to leave produces the $\mathrm{CR}$ in amount of 1.5. It indicates that the value of $\mathrm{CR}<\mathrm{t}$-table. Therefore, it can be meant that there is no significant effect of work life balance to the intention to leave. The effect coefficient of work life balance to the intention to leave is in amount of -0.202 , it expresses that the work life balance has the negative effect to the intention to leave. It means that the better work life balance tends to be able to decrease the intention to leave. However, the third hypothesis is not accepted.

Table- II. Hypothesis test

\begin{tabular}{|c|c|c|c|c|}
\hline Exogenous variable & Endogen variable & Estimate & SE & CR \\
\hline Work Life Balance & Organizational Pride & 0.747 & 0.04 & $18.76^{*}$ \\
\hline Work Life Balance & Job Satisfaction & 0.734 & 0.075 & $9.8^{*}$ \\
\hline Work Life Balance & Intention to Leave & -0.202 & 0.134 & 1.5 \\
\hline Organizational Pride & Job Satisfaction & 0.203 & 0.086 & $2.37^{*}$ \\
\hline Organizational Pride & Intention to Leave & -0.285 & 0.098 & $2.91^{*}$ \\
\hline Job Satisfaction & Intention to Leave & -0.335 & 0.158 & $2.12^{*}$ \\
\hline
\end{tabular}

\section{B. Discussion and Implications}

This research produces some important findings. First, work life balance has the positive effect to the organizational pride. The balance between someone's role in his/her work and family will be implying on the employees behavior to the company. The organizational pride is formed when the employees feel comfortable on the right place because they are able to live balance the life and work.

Second, when the work life balance has the positive effect to the job satisfaction, the company has the important role in creating the comfortable situation for the employees because basically employees are not only demanded by the company, but they also have the personal life. When the employees feel comfortable in living their life, they will feel satisfied on their work and it is important in creating the high employees performance.
The hypothesis test of organizational pride effect to the job satisfaction produces the $\mathrm{CR}$ in amount of 2.37. It indicates that the value of $\mathrm{CR}>\mathrm{t}$-table. Therefore, it can be meant that there is the significant effect of organizational pride to the job satisfaction. The effect coefficient of organizational pride to the job satisfaction is in amount of 0.203 that expresses that the organizational pride has the positive effect to the job satisfaction. It means that the higher organizational pride tends to be able to increase the job satisfaction. However, the fourth hypothesis is accepted.

The hypothesis test of organizational pride effect to the intention to leave produces the $\mathrm{CR}$ in amount of 2.91 . It indicates that the value of $\mathrm{CR}>\mathrm{t}$-table. It means that there is the significant effect of organizational pride to the intention to leave. The effect coefficient of organizational pride to the intention to leave is in amount of -0.285 , it expresses that the organizational pride has the negative effect to the intention to leave. It means that the higher organizational pride tends to be able to decrease the intention to leave. However, the fifth hypothesis is accepted.

The hypothesis test of job satisfaction effect to the intention to leave produces the $\mathrm{CR}$ in amount of 2.12 . It indicates that the value of CR > t-table. It means that there is the significant effect of job satisfaction to the intention to leave. The effect coefficient of job satisfaction to the intention to leave is in amount of -0.335 that expresses that job satisfaction has the negative effect to the intention to leave. It means that the higher job satisfaction tends to be able to decrease the intention to leave. However, the sixth hypothesis is accepted. Table- II presents the hypothesis test.
Third, work life balance does not significantly affect the intention to leave. Result of this research is contradictory with Lingard and Francis [32] which expressed that the practice of WLB is not only necessary, however, it was important as part of the company policy that influences the turnover intention. This research result is also not consistent with Noor [33] and Suifan et.al. [5] which found that WLB practice had the negative and important effect to the turnover intentions. This condition is due to the some job streets that give more chance to the hotel employees for increasing their career in the other company.

Fourth, the organizational pride has the positive and significant effect to the job satisfaction. The proud is as part of company, so the employees will make effort to work better, so it will influence the level of employees work satisfaction. Employees who are proud and 
happy will bring up the satisfaction feeling when they are working on the company which is regarding to their hope. This research result supports the result of Machica et al. [29] and Gouthier and Rhein [13].

Fifth, the organizational pride has the positive and significant effect to the intention to leave. This finding is consistent with Appleberg [15] who presented that the organizational pride has the positive effect to the employees' decision to keep working on the company and it would stimulate the employees commitment to the company. The research result also supports the finding of Yang and Watterberg [35] which presented that the organizational pride was as one of the factors that has the big effect to the turnover intention. This finding also supports the previous finding by Kraemer and Gouthier [16] which presented that the organizational pride had the very important role to the turnover intention.

The last one, the job satisfaction has the positive and significant effect to the intention to leave. The result of this study supports the opinion of Robbins and Judge [36] that was one of the impacts from the employees who were not satisfied to their work place was the outgoing response that was directing their behavior to leave the organization included to find a new position and resignation. This finding strengthens the previous finding by Raddaha et.al. [38] and Masum et.al.[39] which found that the level of nurses work satisfaction very determined their willingness of intention to leave their work place. The relation between job satisfaction and intention to quit is the negative relation which shows that the more level of employees work satisfaction will decrease the level of intention to leave.

Based on our results, a number of practical and managerial implications can be derived. First, the hotel manager has to understand that how important the intention to leave for the company and the factors that cause the intention to leave. The intention to leave can be prevented by work life balance. The employees have the low intention to leave if they get the work situation that is able to synchronize between the work and personal life which means that the employees finish the duty mainly on their company without sacrificing their personal life. The company has the role to create the comfortable work situation for employees related with this balance. The programs of prosperity, family gathering, social help, sport, and the others are relevant to increase the employees' engagement to the company. The strong relation between employees and company will create the employees loyalty to work on the company. This thing is important in the scheme of creating the effective and efficient organization so it has the high competition and performance. Second, the hotel manager has duty to cultivate pride of employees to the company because through the company pride, the employees will feel at home working on the company and they do not have the desire to move. The employees pride is a behavior that shows the employees happiness to the company that can be grown through the company reputation on the society eye as well as the company support to the employees. Regarding to the context of this research, the employees feel proud and love their work when the company gives the chance to the employees to live their personal life during working.

\section{CONCLUSION}

Based on the discussion above, it can be concluded that the work life balance is not directly influencing to the intention to leave. However, the work life balance directly affects the intention to leave through the organizational pride and job satisfaction. It indicates that the organizational pride and job satisfaction have the important role in affecting the work life balance to the intention to leave.

This research has some weakness so there are some recommendations to carry out the next research. First, this research is carried out on the hotel company and is not carried out on the other type of company so the generalization is limited. However, it is recommended to carry out on the other industry. Second, based on the data, it is known that the respondents are varied on the demography, age, and part of them is relatively young. This research has not entered the generation group as the research variable that is predicted will affect the intention to leave. The next research is recommended to enter the demography factor. The last one, this research is cross sectional so it is recommended to carry out the longitudinal research.

\section{REFERENCES}

1. V. Koubova and A. Buchko, "Life-work balance. Management Research Revie”, 36(7), 2013: 700-719.

2. P, Delecta, "Work life balance", International Journal of Current Research, 33 (4), 2011: 186-189

3. D. Vloeberghs, "An original and data based approach to the work-life balance", Equal Opportunities International, 21(2), 2002: 25-57.

4. T.A. Beauregard and L.C. Henry, "Making the link between work-life balance practices and organizational performance", Human Resource Management Review, 19, 2009: 9-22

5. T.S. Suifan, A.B. Abdallah, and H. Diab, "The influence of work life balance on turnover intention in private hospitals: the mediating role of work life conflict", European Journal of Business and Management, ISSN 2222-1905 (Paper) ISSN 2222-2839 (Online), Vol.8, No.20, 2016

6. A.M. Konrad, J.E. Ritchie, P. Lieb, and E. Corrigall, "Sex differences and similarities in job attribute Preferences: a meta-analysis", Psychological Bulletin, 126, 2000: 593-641

7. M. Yadav and S. Rangnekar, "Supervisory support and organizational citizenship behavior", Evidence-based HRM: a Global Forum for Empirical Scholarship, Vol.3 Iss 3., 2014, pp. 258-278

8. T. Kalliath and P. Brough, "Work life balance: a review of the meaning of the balance construct", Journal of Management and Organization, 14(3), July 2008: 323.327

9. S.C. Clark, "Work/ family border theory: A new theory of work/family balance", Human Relations Journal, Vol. 53 (6), 2000: 747-770

10. J. Lewison, "The work/ life balance sheet so far". [1]

[http://www.journalofaccountancy.com/issues/2006/aug/theworklifebal ance heetsofar.html, 2006

11. S. Robbins and M. Coulter, "Management. 9th ed.", Australia: Prentice Hall Pearson Education International, 2012

12. S.A. Haslam, "Psychology in Organizations: The Social Identity Approach ( $2^{\text {nd }}$.end)", London: Sage, 2004

13. M.H.J. Gouthier and M. Rhein, "Organizational pride and its positive effects on employees' behavior", Journal of Service Management, 22 (5), 2011: 633-649.

14. J.L. Tracy and R.W. Robins, "Emerging insights into the nature and function of pride", Current Directions in Psychological Science, Vol. 16 No. 3, 2007, pp. 147-150.

15. K.A. Appleberg, "The construction of a nomo-logical network for organizational pride", Dissertation, Benedictine University, Chicago, I, 2005

16. T. Kraemer and M.H.J. Gouthier, "How organizational pride and emotional exhaustion explain turnover intention in call centers", Journal of Services Management, Vol. 25 No. 1, 2014, pp. 125-148

17. L.D. Grieshaber, P. Parker, and F. Deering, "Job satisfaction of nursing assistants in long-term care", Health 
Care Supervisor, Vol. 13, 1995, pp. 18-28

18. L.D. Grieshaber, P. Parker, and J. Deering, "Job satisfaction of nursing assistants in long-term care", Health Care Supervisor, Vol. 13, 1995,pp. $18-28$

19. L.S. Cowin, M. Johnson, R.G. Craven, and H.W. Marsh, "Causal modeling of self-concept, job satisfaction, and retention of nurses", International Journal of Nursing Studies, 2008, 45(10):1449_1459 DOI 10.1016/j.ijnurstu.2007.10.009

20. G. Yimazel, "Mobbing, job satisfaction and affecting factors in the nurse", Turkiye Clinics Journal of Nursing Science, 5(2), 2013: 55-63.

21. F. Herzberg and B. Mausner, "The motivation to work", New York, NY: Wiley, 1959

22. P.E. Miller, "The relationship between job stress and intention to leave: a study of hospice nurses in a for-profit corporation", Doctoral Disertation, 2007, Available from Pro Quest Dissertation and Theses Database.(UMI No.3246088)

23. P.E. Miller, "The relationship between job stress and intention to leave: a study of hospice nurses in a for-profit corporation". Doctoral Disertation, 2007, Available from Pro Quest Dissertation and Theses Database.(UMI No.3246088)

24. M.E. Mor Barak, J.A. Nissly, and A. Levin, "Antecedents to retention and turnover among child welfare, social work, and other human service employees: What can we learn from past research?", A review and metanalysis. Social Service Review, 75 (4), 2001: 625-661

25. R. Salleh, S.N. Mishaliny, and H. Haryanni, "Job satisfaction, organizational commitment, and turnover Intention: a case study on employees' of a retail company in Malaysia", International Science Index, Vol. 6, No. 12, 2012, pp. 15-22

26. X.P. Chen, C. Hui. and D.J. Sego, "The Role of organizational citizenship behavior in turnover: Conceptualization and Preliminary Tests of Key Hypotheses", Journal of Applied Psychology, 83. 1998: 929-31

27. N. Fiernaningsih, "Influence of commitment to organization, career development, performance appraisal, and job satisfaction towards turnover intention of star-rating hotel employees in Malang", International Journal of Sciences: Basic and Applied Research (IJSBAR) ISSN 2307-4531, Volume 30, No 5, 2016, pp 317-338

28. M.E. Mor Barak, J.A. Nissly, and A. Levin, Antecedents to retention and turnover among child welfare, social work, and other human service employees: What can we learn from past research?" A review and metanalysis. Social Service Review, 75 (4), 2001: 625-661

29. M.M. Machuca, J.B. Mirabent, and Alegre I., Work life balance and its relationship with organizational pride and job satisfaction. Journal of Managerial Psychology, 2015, 31 (Iss.2): 586-602

30. J.M. Haar, M. Russo, A. Surie, and A.O. Malaterre, "Outcomes of work life balance on job satisfaction, Life Satisfaction and Mental Health; A Study Across Seven Culture", Journal of Vocational Behavior, 2014: 361-371

31. Blau and M. Peter, "Exchange and power in social life", NewYork: JohnWiley \& Sons, 1964

32. H. Lingard and V. Francis, "The decline of the 'traditional' family: work-life benefits as a means of promoting a diverse workforce In the construction industry of Australia", Construction Management and Economics, 23(10), 2005: 1045-1057

33. M.M. Machuca, J.B. Mirabent, and I. Alegre I., "Work Liefe Balance and Its Relationship with Organizational Pride and Job Satisfaction". Journal of Managerial Psychology, 31 (Iss.2), 2015: 586-602

34. Noer, Khairunneezam, and Mohd, "Work-life balance and intention to leave among academocsin Malaysian Public Higher Education Institutions", International Journal of Business and social Science, Vol 2 No.11, 2011 (special Issue, June 2011)

35. J. Yang and P. Watteernberg, "Perceived work related factor and turnover intention - a case study of a South Korean Construction Company', Master Thesis, Dadama University, 2016.

36. S.P. Robbins and Judge, "Perilaku organisasi", Buku 2, Jakarta. Salemba Empat, 2008

37. S.P. Robbins and Judge, "Perilaku organisasi", Buku 2, Jakarta. Salemba Empat, 2008

38. A.H.A. Raddaha, J. Alasad, Z.F. Albikawi, K.S. Batarseh, E.A. Realat, A.A. Saleh, and E.S. Froelicher, "Jordanian nurses' job satisfaction and intention to quit", Leadership in Health Services, Vol. 25 No. 3, 2012. pp. 216-231 $q$ Emerald Group Publishing Limited 1751-1879 DOI $10.1108 / 17511871211247651$

39. A.K.M. Masum, M.A.K. Azad, K.E. Hoque, L. Beh, P. Wanke, and O. Alan, "Peer J.", 2016

40. P. Mc. Donald and L.M. Bradley, "The case for work life balance": closing the gap between policy and Practice, 2005,. 20: 20 Series, 15.
41. T.H. Handoko. "Manajemen personalia dan sumber daya manusia". Edisi 2. BPFE, Yogyakarta.2000

\section{AUTHORS PROFILE}

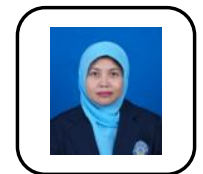

Nilawati Fiernaningsih*, ${ }^{1}$ Doctoral Student, Department of Business Administration, Faculty of Administration, University of Brawijaya, Malang, Indonesia

Umar Nimran, Department of Business Administration, Faculty of Administration, University of Brawijaya, Malang, Indonesia.

Kusdi Rahardjo, Department of Business Administration, Faculty of Administration, University of Brawijaya, Malang, Indonesia.

Zainul Arifin, Department of Business Administration, Faculty of Administration, University of Brawijaya, Malang, Indonesia 